\title{
Hypocholesterolaemic effect of soya-bean proteins
}

\section{By M. J. GiBney, Department of Nutrition, University of Southampton}

Dietary protein has been implicated in atherogenesis on two accounts. First, it may contribute to atherosclerosis through the formation of antibodies to food protein and the initiation of endothelial injury through the involvement of immune complexes (Gallagher et al. 1980). Secondly, dietary protein can exert a considerable influence on the level of serum cholesterol and can thus indirectly influence the development of atheroma. In both cases the effect is species dependent.

\section{Animals}

The effect of dietary protein source on serum cholesterol has been extensively studied in rabbits and the major contributions have come from Carroll and his coworkers. Their results are summarized in Table $\mathrm{I}$. Clearly, animal proteins are hypercholesterolaemic relative to plant proteins although within each category there is considerable variation. The effect of dietary protein source on serum cholesterol in the rat, pig, chicken and mouse is summarized in Table 2. In the non-cholesterol-fed rat there have been several reports indicating that the concentration of serum cholesterol is lower with soya bean as opposed to casein feeding. However, the magnitude of this reduction is substantially less with rats than with rabbits, reaching statistical significance in only some studies (Hevia et al. 1979; Sautier et al. 1979; Pathirana et al. 1980; Kato et al. 1981; Nagata et al. $198 \mathrm{I})$. The addition of cholesterol $(\mathrm{I} 0 \mathrm{~g} / \mathrm{kg})$ to the diet enhances the hypercholesterolaemic effect of animal proteins in rats (Hevia et al. 1979) while the addition of both cholesterol and cholic acid ( $10-20 \mathrm{~g}$ and $2 \cdot 5-5 \mathrm{~g} / \mathrm{kg}$ respectively) have an even greater effect on hypercholesterolaemia (Yadav \& Liener, 1977; Nagata et al. 1981). The results of Nagata et al. (1980) suggest that much of this variation in the effects of dietary protein on rat serum cholesterol can be attributed to variations in the level and source of dietary fat. In contrast to the rat, the addition of cholesterol to the diet of the rabbit produces such a massive hypercholesterolaemia as to dwarf any effect of dietary protein (Pathirana et al. 1979).

The hypocholesterolaemic effect of soya-bean protein has been studied in other species and the general pattern is one of animal protein exerting a hypercholesterolaemic effect in the cholesterol supplemented diets of pigs (Forsythe et al. 1980; Kim et al. 1980), mice (Roy \& Scheeman, 1981) and chickens (Kritchevsky et al. 1959; Hevia et al. 1979).

\section{Humans}

There is considerable disagreement in the literature as to the effect of soya-bean protein on serum cholesterol in normo- and hyper-lipaemic patients. Studies by 
Table 1. The effect of dietary protein source on plasma cholesterol in rabbits fed on low-fat, cholesterol-free diets"

(Values are means with their standard errors)

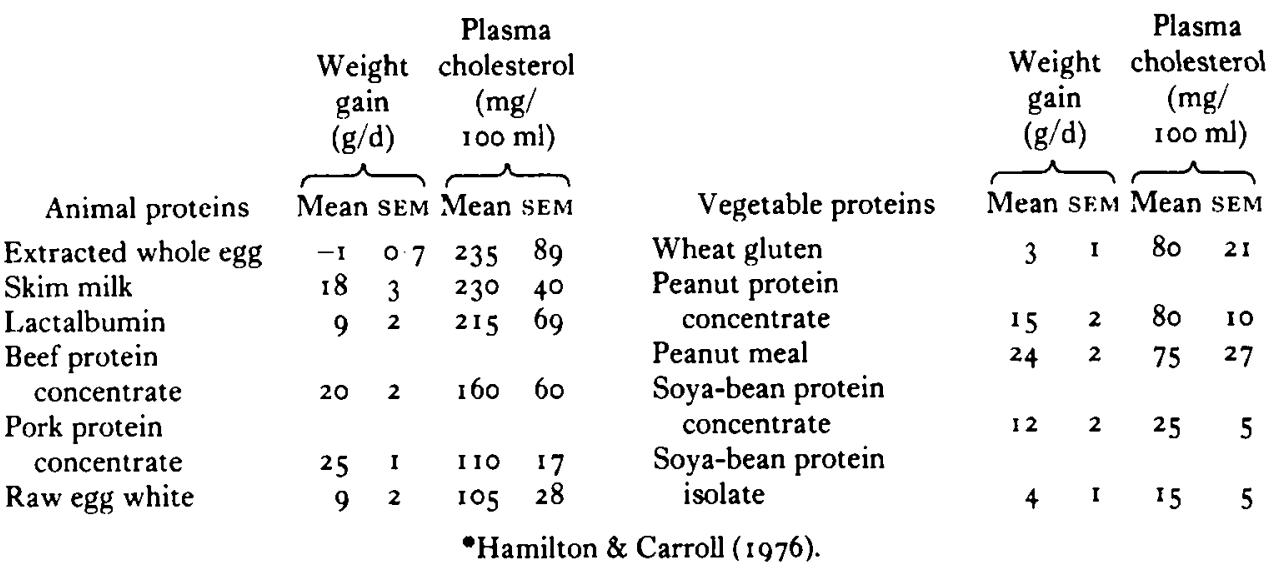

Table 2. The effect of dietary protein source on serum cholesterol in the rat, pig, chicken and mouse

(Values are means with their standard errors)

\begin{tabular}{|c|c|c|c|c|c|c|}
\hline \multirow[b]{2}{*}{ Reference } & \multirow[b]{2}{*}{ Species } & \multirow{2}{*}{$\begin{array}{c}\text { Dietary } \\
\text { cholesterol } \\
(\mathrm{g} / \mathrm{kg})\end{array}$} & \multirow{2}{*}{$\begin{array}{l}\text { Dietary } \\
\text { cholic acid } \\
(\mathrm{g} / \mathrm{kg})\end{array}$} & \multirow{2}{*}{$\begin{array}{l}\text { Dietary } \\
\text { protein }\end{array}$} & \multicolumn{2}{|c|}{$\begin{array}{c}\text { Serum } \\
\text { cholesterol } \\
(\mathrm{mg} / \mathrm{r} 00 \mathrm{ml}\end{array}$} \\
\hline & & & & & Mean & SEM \\
\hline Sautier et al. (1979) & Rat & 0 & 0 & $\begin{array}{l}\text { Casein } \\
\text { Soya bean }\end{array}$ & $\begin{array}{l}9^{2} \\
9^{2}\end{array}$ & $\begin{array}{r}10 \\
6\end{array}$ \\
\hline Hevia et al. (1979) & Rat & 10 & 0 & $\begin{array}{l}\text { Casein } \\
\text { Soya bean }\end{array}$ & $\begin{array}{l}154 \\
137\end{array}$ & $\begin{array}{r}8 \\
10\end{array}$ \\
\hline Nagata et al. (1980) & Rat & I0 & $2 \cdot 5$ & $\begin{array}{l}\text { Casein } \\
\text { Soya bean }\end{array}$ & $\begin{array}{l}233 \\
157\end{array}$ & $\begin{array}{l}29 \\
22\end{array}$ \\
\hline Yadav \& Liener (1977) & Rat & 20 & $5 \cdot 0$ & $\begin{array}{l}\text { Casein } \\
\text { Soya bean }\end{array}$ & $\begin{array}{l}363 \\
208\end{array}$ & $\begin{array}{l}60 \\
22\end{array}$ \\
\hline Forsythe et al. (1980) & Pig & 20 & 0 & $\begin{array}{l}\text { Animal } \\
\text { Vegetable }\end{array}$ & $\begin{array}{l}205 \\
15^{8}\end{array}$ & 9 \\
\hline Roy \& Scheeman ( $198 \mathrm{r}$ ) & Mouse & I0 & $5 \cdot 0$ & $\begin{array}{l}\text { Casein } \\
\text { Soya bean }\end{array}$ & $\begin{array}{l}180 \\
149\end{array}$ & $\begin{array}{l}5 \\
7\end{array}$ \\
\hline Kritchevsky et al. (1959) & Chicken & 30 & 0 & $\begin{array}{l}\text { Casein } \\
\text { Soya bean }\end{array}$ & $\begin{array}{l}539 \\
3^{6} 5\end{array}$ & - \\
\hline
\end{tabular}

Sirtori et al. (1979), Karlstrom et al. (1979), Descovich et al. (1980) and Wolfe et al. ( 1980 ) demonstrated a significant reduction in serum cholesterol in types IIa, IIb and IV hyperlipidaemic patients. The studies of Sirtori et al. (1979) and Descovich et al. (1980) showed that this effect was not influenced by dietary cholesterol, was generally greatest when used in conjunction with diets rich in polyunsaturates and was evident with both familial and non-familial hyperlipidaemic patients. Similarly, Carroll et al. (1978) found a significant reduction 
with soya-bean feeding in the serum cholesterol levels of normolipaemic female volunteers. In contrast, Shorey \& Davis (1979) and Holmes et al. (1980) failed to find a hypocholesterolaemic effect of soya-bean protein in hyperlipidaemic patients, while van Raaij et al. (1979) and Bodwell et al. (1980) obtained negative results in healthy volunteers. Those studies which revealed a hypocholesterolaemic effect of soya-bean protein with hyperlipidaemic patients were distinguished by a high proportion of dietary energy from protein and a low proportion from fat, the use of diets in which the fat was highly polyunsaturated and the investigation of patients whose initial serum cholesterol values were very high.

\section{Cholesterol metabolism}

The rate limiting step in cholesterol biosynthesis is the conversion of $\beta$-hydroxy$\beta$-methylglutaryl coenzyme A (HMG-CoA) to mevalonate and the key enzyme involved in this step is HMG-CoA reductase. Several authors have studied the effect of dietary protein on HMG-CoA reductase activity. Reiser et al. (1977) found that hepatic HMG-CoA reductase activity was twice as great in soya-beanfed as casein-fed rats. Kritchevsky et al. (1979) found that supplementary feeding of whole or skim milk to rats suppressed the hepatic HMG-CoA reductase activity compared with controls fed on a stock diet. Carroll (1967) also found that the addition of casein to rabbit stock diet significantly reduced acetate incorporation into cholesterol. Kim et al. (1980) found no significant difference between soya bean and casein in their effect on hepatic HMG-CoA reductase activity in the cholesterol-fed pig. However, it is likely that cholesterol feeding per se had an over-riding suppressive effect on cholesterol synthesis in this experiment. The activity of the enzyme plasma lecithin-cholesterol acyltransferase (LCAT) was found to be significantly reduced in pigs fed on animal protein as opposed to vegetable protein diets. However, Bosisio et al. (1980) failed to find any significant difference in LCAT activity between soya-bean- and casein-fed rats. These same authors failed to find any difference in the activity of rat hepatic $7^{-\alpha}$ hydroxylase with casein or soya-bean diets.

The changes which occur in serum cholesterol with different proteins generally occur in the very-low- and low-density lipoprotein fractions (Terpstra \& SanchezMuniz, 198I; Pathirana, 198I). Nagata et al. (198I) found that soya-bean feeding, as opposed to casein feeding led to increased serum concentrations of apolipoproteins $B$ and $E$ in the rat both of which are associated with the very-low-and low-density lipoproteins. However, the concentration of apo-AI, the major apoprotein of the high-density lipoprotein fraction was significantly lower in soyabean- than in casein-fed rats. Terpstra \& Sanchez-Muniz ( $198 \mathrm{r}$ ) also found lower HDL apo-protein with soya-bean-fed rabbits. However, concentrations of apolipoproteins do not reveal anything of the nature of the turnover of the cholesterol component of the lipoprotein particle.

Roberts et al. (1981) have studied the turnover of ${ }^{125}$ I-labelled intermediate density lipoproteins and found that in casein-fed rabbits, the turnover was 
considerably longer than in soya-bean-fed animals. These workers also noted that apo-protein transfer from very-low- to high-density liproproteins was significantly greater in soya-bean-fed, than casein-fed rabbits. This effect appeared to be partly due to changes in the apo-protein fraction of the very-low-density lipoprotein fraction and partly due to changes in the catabolism of these lipoproteins. Similarly, Huff \& Carroll (1980a) found that the turnover of injected $\left[{ }^{14} \mathrm{C}\right]$ cholesterol was approximately twice as fast in soya-bean-fed as opposed to caseinfed rabbits. These experiments complement the observation of Pathirana et al. ( $198 \mathrm{r}$ ) and Nagata et al. ( $198 \mathrm{I}$ ) that soya-bean-fed rabbits and rats have a greater faecal output of bile acids and neutral sterols than animals fed on cow's milk protein diets. Cholesterol absorption is significantly greater in casein-fed rabbits and the oxidation of cholesterol to bile acids is also significantly greater in soyabean-fed rabbits (Huff \& Carroll, I980a).

\section{Mechanism of hypocholesterolaemia}

The hypocholesterolaemic effect of soya-bean protein is not due to the complex carbohydrates present in soya beans for several authors have shown that soya-bean flour, with up to $400 \mathrm{~g}$ carbohydrate/ $\mathrm{kg}$ is no more hypocholesterolaemic than the soya-bean protein isolates with only trace quantities of complex carbohydrate. Potter et al. (1979) proposed that saponins are the hypocholesterolaemic agents of soya-bean protein products. These saponins are present in whole soya beans $\left(5^{6} \mathrm{~g} / \mathrm{kg}\right)$, soya-bean flour $(22 \mathrm{~g} / \mathrm{kg})$ and soya-bean protein isolate $(3 \mathrm{~g} / \mathrm{kg})$, and have the ability in vitro to cause the adsorption of bile acids to dietary fibre. Oakenfull $e t$ al. (1979) postulated that soya-bean saponins would lead to increased faecal excretion of sterols and a subsequent reduction in blood cholesterol. This appears to be the case where hypercholesterolaemia is achieved by exogenous dietary cholesterol (e.g. Oakenfull et al. 1979). However, Pathirana et al. (1981) have found that saponins do not lower serum cholesterol in rabbits rendered hypercholesterolaemic by milk protein feeding. Other studies, with humans, have failed to demonstrate a significant effect of saponins on serum cholesterol in soya-bean feeding (Calvert et al. 198I).

The possibility that the amino acid composition per se is responsible for the cholesterolaemic effect of dietary protein has been investigated by several authors. Huff \& Carroll ( $1980 b$ ) have shown that mixtures of amino acids that are similar in composition to animal protein (extracted egg yolk and casein) are equally as hypercholesterolaemic in rabbits as with the intact protein. However, mixtures of amino acids designed to simulate vegetable proteins (e.g. soya bean or sunflower) are generally much more hypercholesterolaemic in rabbits than the intact protein. Taken together, these results indicate that the hypocholesterolaemic effect of vegetable protein is largely dependent on the intact protein per se whereas the hypercholesterolaemic effect of animal protein is completely determined by the amino acid composition of the protein. These differences may arise from variation in the rates of digestion and absorption of the two groups of dietary protein. 
Nagata et al. (198I) found similar results with rats while Yadav \& Liener (1977) found amino acids mixtures to be equally effective to whole soya bean and casein in chicks fed high-cholesterol, high-cholic acid diets.

Several authors have examined the specific effects of individual amino acids on serum cholesterol in animals fed on soya bean or casein. Kritchevsky (1979) postulated that the lysine:arginine value was important and Kritchevsky et al. (1979) have shown that supplementation of soya bean with lysine to the level of casein led to a significant rise in serum cholesterol and aortic atherosclerosis. The addition of arginine to casein to raise its level to that found in soya-bean protein had an opposite effect on serum cholesterol and aortic atheroma. No physiological explanation has been proposed to explain why the lysine:arginine value is critical. Nagata et al. ( $\mathrm{r} 98 \mathrm{r}$ ) found that lysine and arginine supplementation of soya bean and casein respectively or indeed amino acids mixtures similar to soya bean or casein, had no significant effect on rat serum cholesterol, serum apo-lipoproteins $A-I, B$ and $E$, and faecal excretion of acid and neutral sterols. Huff \& Carroll $(\mathrm{r} 98 \mathrm{o} b$ ) examined the effect of adding groups of amino acids to soya bean or casein on rabbit serum cholesterol and although they effected changes in serum cholesterol, these authors could not identify any single amino acid or group of amino acids (e.g. essential $v$. non-essential) as being the important factors in serum cholesterol population. Hermus (1979) found that supplementation of casein with alanine, arginine and glycine, the three amino acids most limiting in casein compared to soya bean, tended to lower serum cholesterol in casein-fed rabbits. Lysine, methionine and arginine appeared to have no effect, while glycine had a hypocholesterolaemic effect when added to casein.

\section{Conclusions}

The speed with which the indices of cholesterol metabolism in rabbits alter in response to a dietary change from soya bean to casein or vice-versa, suggest that a metabolic adaptation is taking place rather that a longer term adaptation such as an alteration in the micro-flora of the large intestine (Terpstra \& Sanchez-Muniz, I 981 ). One possible explanation which in the absence of any alternative hypothesis seems an attractive area of investigation is that hormones mediate the cholesterolaemic effect of dietary protein. The hormones, insulin and glucagon are correlated positively and negatively respectively with the substantial diurnal variation in rat hepatic HMG-CoA reductase activity (Nepokroeff et al. 1974). Clearly, if dietary protein could alter post-prandial response to insulin, a mechanism exists for increasing cholesterol synthesis from the liver (as happens with soya bean) by stimulating HMG-CoA reductase and for increasing the turnover of very-lowdensity lipoproteins (as happens with soya bean) by stimulating extra-hepatic lipoprotein lipase activity. We have investigated the effect of different dietary proteins of post-prandial insulin release in five healthy male volunteers aged I9-39, following a meal of $4.2 \mathrm{MJ}(50,25$ and $25 \%$ energy from fat, carbohydrate and protein respectively) in which butter provided the fat source, lactose provided 
carbohydrate and protein was provided by isolated soya-bean protein or cow's milk proteins (casein). The results are shown in Fig. I. Soya-bean feeding led to a peak increase after the control of butter + glucose whereas the milk - protein meal led to a significantly reduced post-prandial insulin release. Whether these effects are due to the direct action of nutrients on the pancreas or whether they are a consequence of alterations in stomach emptying is uncertain. Several amino acids are known to act as insulin and glucagon secretogogues (Fajans et al. 1967; Eisenstein \& Strack, 1978). Arginine is the most powerful secretogogue of both hormones among the amino acids. Soya-bean protein and other vegetable proteins are particularly rich in arginine and it may well be that release of arginine following soya-bean digestion leads to an enhanced stimulation of insulin release. Noseda et al. (1980), however, did not find any changes in the mean basal insulin levels of type II patients following a cholesterol lowering soya-bean diet. However, these authors recorded a significant increase in the peak glucagon release following

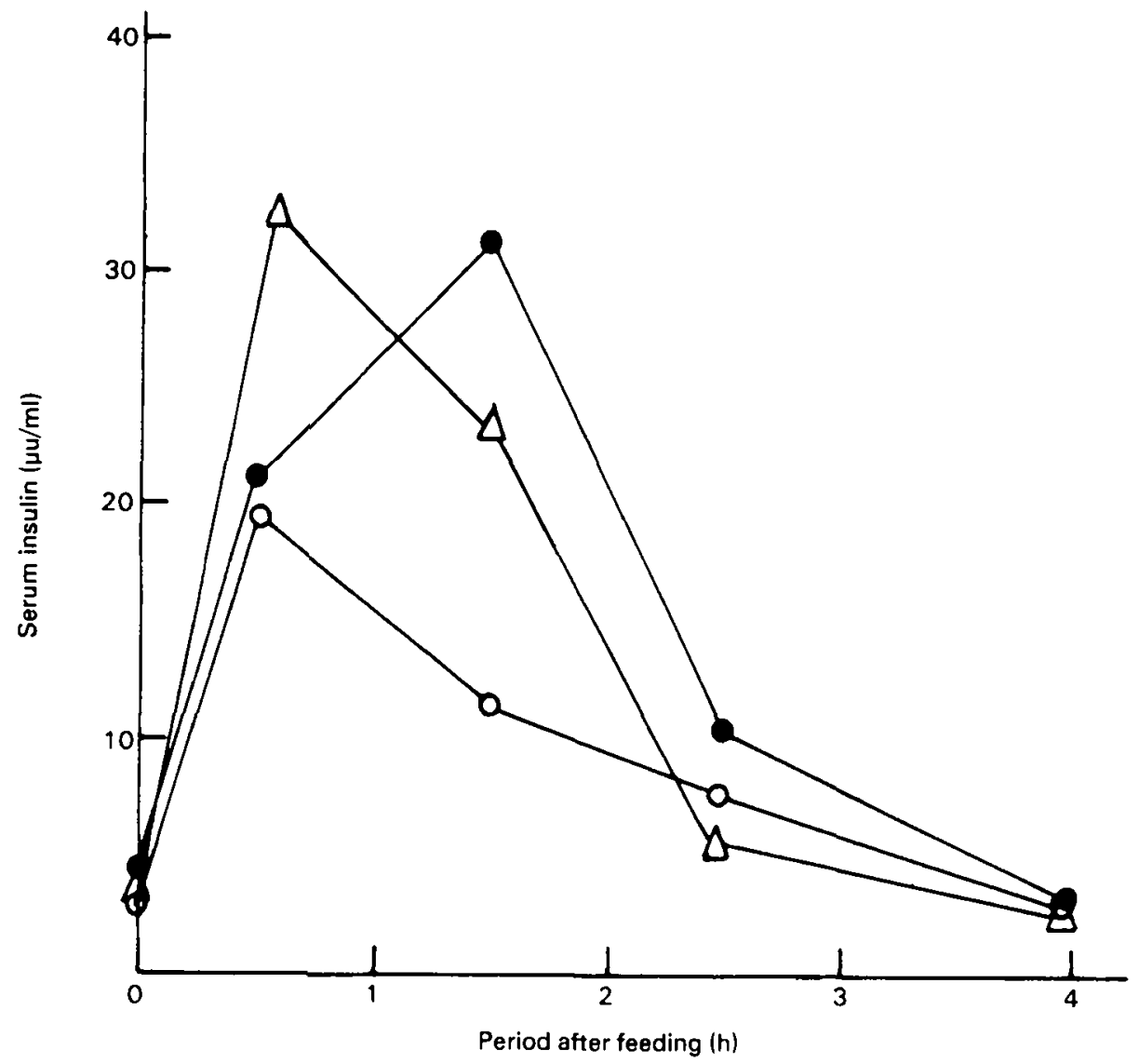

Fig. I. Serum insulin $(\mu \mathrm{u} / \mathrm{ml})$ following the consumption of a test meal $(4 \cdot 2 \mathrm{MJ})$ by five healthy male volunteers; $(O)$ casein; $(O)$ isolated soya-bean protein, glucose and butter; $(\triangle)$ glucose and butter. The distribution of energy in the protein containing meals was, protein-fat-carbohydrate; I:2:1. 
arginine stimulation in soya-bean treated hyperlipidaemic patients. However, it is quite possible that this effect on glucagon was a consequence of a high-protein intake per se (Eisenstein \& Strack, 1978). Although any proposed role for insulin and glucagon in the regulation of serum cholesterol by dietary protein is conjectural it does have some attractions as an initial hypothesis.

\section{REFERENCES}

Bodwell, C. E., Schuster, E. M., Steele, P. S., Judd, J. T. \& Smith, J. C. (1980). Fedn Proc. Fedn Am. Socs exp. Biol. 39, I I 13.

Bosisio, E., Galli-Kienle, M., Galli, G., Ghiselli, G. C., Francheschini, G. \& Sirtori, C. R. (I980). Proc. VIIth Int. Symp. Drugs Affecting Lipid Metabolism, Milan. p. 274.

Calvert, G. D., Blight, L., Illman, R. J., Topping, D. L. \& Potter, J. D. (r98 s). Br. F. Nutr. 45, 277.

Carroll, K. K. (1 967). Atherosclerosis 13,67.

Carroll, K. K., Giovanetti, P. M., Huff, M. W., Moase, O. \& Roberts, D. C. K. (1978). Am. $\mathcal{F}$. clin. Nutr. 31, iziz.

Descovich, G. C., Gaddi, A., Mannino, G., Cattin, L., Senin, U., Caruzzo, C., Fragiocomo, C., Sirtori, M., Ceredi, C., Benassi, M. S., Colombo, L., Fontana, G., Mannarino, E., Bertelli, E., Noseda, G. \& Sirtori, C. R. (I980). Lancet ii, 709.

Eisenstein, A. B. \& Strack, J. (1978). Diabetes 27, 370.

Fajans, S. S., Floyd, J. C., Knopf, R. F. \& Conn, J. W. (1967). Rec. Prog. Horm. Res. $23,617$.

Forsythe, W. A., Miller, E. R., Hill, G. M., Romsos, D. R. \& Simpson, R. C. (1980). F. Nutr. I ro, 2467.

Gallagher, P. J., Gibney, M. J. \& Taylor, T. G. (1980). Artery 8, 3 I 5.

Hamilton, R. M. G. \& Carroll, K. K. (1976). Atherosclerosis $24,47$.

Hermus, R. J. J. (1979). Proc. 3rd Eur. Nutr. Conf., Var Foda 31, Suppl. I81.

Hevia, P., Clary, R. A. \& Visek, W. J. (1979). Nutr. Rep. int. 20, 539.

Holmes, W. L., Rubel, G. B. \& Hood, S. S. ( 1980). Atherosclerosis 36, 379.

Huff, M. W. \& Carroll, K. K. ( I $980 a)$. F. Lipid. Res. 21, 546.

Huff, M. W. \& Carroll, K. K. (1980b). F. Nutr. 1 10, 1676.

Karlstrom, B., Boberg, J., Gustaffson, I-J, Lithell, H., Vessby, B. \& Werner, J. (1979). Proc. 3rd Eur. Nutr. Conf., Var Foda. 31, Suppl. I 88.

Kato, N., Tani, T. \& Yoshida, A. (198I). F. Nutr. $111,123$.

Kim, D. N., Lee, K. T., Reiner, J. M. \& Thomas, W. A. (1980). In Proc. VII Int. Symp. Drugs Affecting Lipid Metabolism, Abstract book, p. 273.

Kritchevsky, D. (1979). \%. Am. Oil. Chem. Soc. 56, 1 35.

Kritchevsky, D., Kolman, R. R., Gutmacher, R. M. \& Forbes, M. (1959). Arch. Biochem. Biophys. 85,444 .

Kritchevsky, D., Tepper, S. A., Morrissey, R. B., Czaeneck, S. K. \& Klurfeld, D. M. (I979). Am. 7. clin. Nutr. 32, 597 .

Nagata, Y., Imaizumi, K. \& Sugano, M. (1980). Br. F. Nutr. 44, 113.

Nagata, Y., Tamaka, K. \& Sugano, M. (I98I). Br. $\mathcal{F}$. Nutr. 45, 233.

Nepokroeff, C. M., Lakshmanan, C. M., Ness, G. C., Dugan, R. E. \& Porter, J. W. (1974). Biochem. Biophys. Res. Commun. 50, 704.

Noseda, G., Fragiacomo, C., Descovich, G. C., Fumgelli, R., Beranini, F. \& Sirtori, C. R. (1980). Proc. VII Int. Symp. Drugs Affecting Lipid Metabolism, Milan, p. 275.

Oakenfull, D. G., Fenwick, D. E., Hood, R. L., Topping, D. L., Illman, R. L. \& Storer, G. B. (I979). Br. F. Nutr. 42, 209.

Pathirana, C. (1981). PhD thesis, University of Southampton.

Pathirana, C., Gibney, M. J. Gallagher, P. J. \& Taylor, T. G. (1979). Proc. Nutr. Soc. 38, 26 A.

Pathirana, C., Gibney, M. J. \& Taylor, T. G. (1980). Atherosclerosis 36, 595 .

Pathirana, C., Gibney, M. J. \& Taylor, T. G. (I98I). Br. J. Nutr. 46, 421 .

Potter, J. D., Topping, D. L. \& Oakenfull, D. (1979). Lancet i, 223. 
Reiser, R., Henderson, G. R., O'Brien, B. C. \& Thomas, J. (1 977). F. Nutr. 107, 453.

Roberts, D. C. K., Stalmach, M. E., Khalil, M. W., Hutchinson, J. C. \& Carroll, K. K. (r98r). Can. F. Biochem. (In the Press).

Roy, D. M. \& Scheeman, B. D. (1981). F. Nutr. 111,878 .

Sautier, C., Doucet, C., Flament, C. \& Lemonnier, D. (1979). Atherosclerosis 34, 233.

Shorey, R. L. \& Davis, J. L. (1979). Fedn Proc. Fedn Am. Socs exp. Biol. 380, 551.

Sirtori, C. R., Gatti, E., Montero, O., Conti, F., Agradi, E., Tremoli, E., Sirtori, M., Fraterigo, L., Torazzi, L. \& Kritchevsky, D. (1979). Am. f. clin. Nutr. 32, 1645.

Terpstra, A. H. M. \& Sanchez-Muniz, F. J. (1981). Atherosclerosis 39, 217.

van Raaij, J. M. A., Katan, M. B. \& Hautvast, J. G. A. J. (1979). Lancet ii, $95^{8}$.

Wolfe, B. M., Gioraneti, P. M., Huff, M. W., Moase, O. \& Roberts, D. C. K. (1980). Circulation 62, Suppl III, 227.

Yadav, N. R. \& Liener, I. E. (1977). Nutr. Rep. int. 16, 385. 